\title{
THE USE OF EARNED VALUE MANAGEMENT FOR INITIATING DIRECTIVE PROJECT CONTROL DECISIONS: A CASE STUDY
}

\author{
N. H. Nkiwane $1^{\#}$, W. G. Meyer ${ }^{1 *} \&$ H. Steyn ${ }^{1}$
}

\section{ARTICLE INFO}

\section{Article details}

Submitted by authors 27 May 2015

Accepted for publication 22 Feb 2016

Available online $\quad 10$ May 2016

\# The author was enrolled for an $M$ Eng. (Project Management) degree in the Department of Engineering and Technology Management, University of Pretoria.

\section{Contact details}

Corresponding author

werner@projectlink.co.za

Author affiliations

1 Department of Engineering and Technology Management, Graduate School of Technology Management

University of Pretoria

South Africa

\section{DOI}

http://dx.doi.org/10.7166/27-1-1260

\section{ABSTRACT}

With large infrastructure backlogs in Africa, well-controlled projects will play a significant role in African infrastructure development. In this paper, the monitoring and/or directive use of Earned Value Management (EVM) is investigated and linked to project management maturity. This case study also investigates the use of EVM based on the financial and schedule risk distribution among project role players, and the effect of EVM on project performance. The results show minimal use of EVM in the directive control of projects; at best, the directive use of EVM is found to be implied rather than deliberate and methodical.

\section{OPSOMMING}

Met groot agterstande in infrastruktuur in Afrika kan goedbeheerde projekte ' $n$ beduidende rol in die ontwikkeling van infrastruktuur speel. In hierdie artikel word die monitering en direktiewe gebruik van verdiende-waarde bestuur (VWB) ondersoek en gekoppel aan projekbestuur volwassenheid. Die gebruik van VWB op projek prestasie is ook ondersoek aan die hand van 'n geval. Die resultate toon minimale gebruik van VWB in die direktiewe beheer van projekte; die direktiewe gebruik van VWB is hoogstens implisiet eerder as feitelik.

\section{INTRODUCTION}

Projects are executed within the constraints of time, budget, and quality, and a project manager should exercise control to ensure project delivery within these constraints. The South African government remains the biggest investor in infrastructure development projects. From 2009 to 2012, over ZAR 860 billion was spent on infrastructure projects; a further ZAR 4 trillion is planned for the period from 2013 to 2030 [2,3], which includes an estimated ZAR 827 billion between 2013 and 2016 [1].

Most of the infrastructure development projects are developed against a backdrop of urgent need, with pressure to deliver. Examples from South Africa include the Reconstruction and Development Programme (RDP), the Accelerated Schools Infrastructure Development Initiative (ASIDI), Eskom's and Transnet's capacity expansion programmes, the Gautrain Project, and the 2010 FIFA World Cup stadiums. A common attribute of these projects is that they often address needs rather than opportunities, and as such are executed with beneficiaries and other stakeholders already waiting and demanding delivery. Service delivery protests attest to this, and on-time delivery is therefore a high priority ${ }^{1}$.

1 South Africa has seen a dramatic rise in service delivery protests since 2012. The most common reasons for protests are grievances around urban land, housing, and basic services such as water, electricity, and sanitation. From November 2013 to January 2014 over 3000 protest actions were recorded involving more than 1 million people [26]. 
Given the planned infrastructure spend and the conditions of pressure under which these projects will be executed, it is clear that project management will have a huge role to play in South Africa, and project control will be central to the delivery of these projects. The National Development Plan (NDP) also outlines how South Africa aims to be the leader in continent-wide development. The expansion of ports, roads, airports, and transport hubs are being earmarked not just to stimulate South African growth, but also to establish South Africa as the gateway into the rest of Africa [4]. Projects and project management are going to play a huge role in infrastructure development in Africa, with the rest of the world and South Africa playing a leading role in the delivery of this infrastructure. Project control is one of the biggest challenges that project managers face in the construction industry, and indications are that South Africa is no exception $[5,6]$. Delivery dates are continually pushed back and costs inevitably rise. Project control tools and their effective use are key to delivering projects within the triple constraints of cost, time, and quality [7-9].

The South African government also seeks continually to empower small-to-medium scale contractors by awarding projects to promising contractors. But these contractors often fail to make profits from the projects and become bankrupt. As a result, contractors often abandon unfinished projects, forcing government to procure other contractors to finish the job at an additional cost. This scenario emphasises the need for project management skills to control and direct projects [10].

Various models for project control have been developed. In the construction industry, these include the leading parameter model, activity based ratios, variances, and Earned Value Analysis [7].

Earned Value Management (EVM) is widely accepted as a best practice in project control. From its beginnings in the United States' Department of Defence (USDoD) [11-13] to its current more evolved forms, EVM continues to evolve to suit all project types and sizes. In South African infrastructure projects, however, its uptake has been slow [14]. Project performance in terms of cost and schedule is often poorly communicated and is seen as privileged information. In contrast, project safety and quality performance is well-communicated and has a direct effect on daily project work and decisions. Performance parameters such as the target Lost Time Injury (LTI) free hours, achieved LTI-free hours, and acceptable and defective work quality-wise, often resonate better with project teams than schedule- and budget-related project performance parameters such as how far behind or ahead of schedule the project is. This general awareness has an effect on decisions at all levels of the project team, and these decisions aggregate to impact on the project's performance. Boeing found that the value of well-communicated project performance on aircraft assembly projects, in terms of EVM metrics, made a significant positive impact on the performance of workers [15]. Past research has identified various barriers to the implementation of EVM $[13,14,16]$, but falls short of explaining how its use is realised at different levels of the project team.

Control is composed of two elements: (a) measuring and monitoring, and (b) giving direction, which is referred to here as directive control. EVM metrics such as Cost Variance (CV), Schedule Variance (SV), Cost Performance Index (CPI), and Schedule Performance Index (SPI) refer to the past and are monitoring tools. Metrics such as the Estimate at Completion (EAC) and the To Complete Performance Index (TCPI) refer to future project performance, and can be used for directive control decisions affecting future project performance.

In this research, the use of Earned Value Management/Analysis (EVM/A) as a project control tool in an infrastructure construction project in South Africa is investigated to determine how EVM could be implemented to make more directive decisions in infrastructure projects, and how EVM affects daily project work.

\section{$1.1 \quad$ Objectives}

A research project with the following objectives was carried out:

- To determine how EVM can be used as an input to initiate directive control actions to influence project outcomes positively in an infrastructure project in South Africa, and how the control decisions filter down to the project executors and result in sustained action from the decision-makers to day-to-day project activities. 
- To determine the effect of EVM on project performance, and why this effect has been realised.

- To determine whether the motivation for implementing EVM as a project control tool is affected by the distribution of financial and schedule risk amongst contracting parties, and whether the lack of including EVM in the contractual agreement diminishes the effectiveness of EVM when projects are executed.

\section{LITERATURE SURVEY}

Song and Shalini [16] showed that the adoption of EVM by project practitioners is mostly voluntary. This suggests that EVM is recognised as a leading practice method for tracking project progress, as well as monitoring and controlling performance. Kim et al. [13] made similar findings.

Clients implement EVM mostly in large, high-risk projects and cost-plus-incentive projects, whereas contractors do not consider the contract type when deciding to implement EVM [16]. Anbari et al. [17] also found that EVM was more applicable to large projects. The cost-risk element as motivation for implementation is expected, as project performance directly affects contractor performance, whereas the client's benefit from the project is realised upon project completion; thus the client would be more interested in controlling the risk that they carry during project implementation. For example, in Municipal Infrastructure Grant (MIG) projects, on-time delivery is rated higher than cost control due to social and political pressure [14], and therefore motivation to implement a methodology that would allow for control of the schedule is expected to be high. In this research, the attitudes of the clients, contractors, and consultants with regard to EVM implementation in relation to financial risk distribution were investigated.

Various researchers have found knowledge and understanding to be a barrier to EVM implementation $[13,14]$. In fact, the factors found by these researchers point to problems in the project environment, such as project maturity and readiness, rather than the technical applicability of EVM.

EVM implementation can be seen as a pull factor that requires best project management practices to be in place in order for it to be used to monitor and direct projects. The level of project management excellence or development in an organisation is referred to as "project management maturity'. Most maturity models use a five-point scale to grade an organisation's project management maturity $[20,23]$. It was found that organisations with a maturity level of three or higher are candidates for EVM [20].

People tend to resist implementation of new methods that require new learning for fear of relinquishing power. Furthermore, poor performance results in repercussions for the project team; hence there tends to be a reluctance to reveal true project performance. In the case of publiclyfunded infrastructure projects, political pressure also plays a significant role, as opposition parties can use poor performance to gain political mileage with the electorate [14]. In the chosen case for this study, EVM was already being used. Of interest are the factors that limit or enhance the use and effectiveness of EVM, particularly as an input to directive control decision-making.

Directive control should be possible in infrastructure projects; first, to influence the contractor to perform to the desired contractual levels; and second, to influence the contractor to perform to new levels that require some contractual change. While the second situation is a clear-cut issue that requires consensus, the first condition is a little more complicated, particularly in large, longduration contracts. Due to variations, claims, compensation events, and disputes, nonperformance is disputable because it can be protected by means of these claims, which are granted as time extensions on the end date. Further, a contractor's response to motivation efforts may be influenced by the relationship with the client and the possibility of obtaining future contracts. Wong et al. [6] found that contractors are more willing to adjust performance and conform to a client's directive control with the intention of keeping the client happy in the hope of obtaining future work. If this relationship is strained, the contractor's willingness to respond to such control may be diminished.

\subsection{EVM methodology}

The Earned Value Analysis integrates time, cost, and quality, and traditionally measures performance deviations in financial terms. This measure is sometimes difficult to communicate to 
all levels of the project; for example, a schedule variance of ZAR 1 million sounds confusing. Performance indices - the Schedule Performance Index (SPI) and Cost Performance Index (CPI) limit this problem, but an even better metric is the EVM extension, Earned Schedule (ES) [18]. ES measures schedule performance in time units, which are defined as the point in time at which the value at the time of assessment should have been achieved $[9,19]$. Graphically, it is obtained by projecting the EV line horizontally to intersect the planned value curve, as shown in Figure 1, where the time of assessment (AT) is shown as AT=8. Although ES can also be determined mathematically, the formulae are excluded from this paper, but can be found in Vandevoorde and Vanhoucke [9], Lipke [18], and Lipke et al. [19].

At the heart of EVM is the measurement of progress. Various methods are used for measuring progress, and are classified as qualitative (e.g., units completed, incremental milestones, and start to finish), quantitative (e.g., level of effort and individual judgement), combination methods, or apportioned progress [20]. Measuring progress can be time-consuming and expensive, and it must be kept in mind that in most cases progress is an estimate, and too much effort should not be given to refining the measurement.

In infrastructure construction, however, determination of progress is often relatively simple. Progress data is captured for payment claims and, if specified in the contract, the cumulative percentage progress may also be measured.

\subsubsection{Forecasting}

Schedule variance (SV), SPI, cost variance (CV), and CPI are indicative of past performance. EVM has an added value in its ability to forecast the estimate at completion (EAC), or time estimate at completion (TEAC) in the case of ES. These forecasts are based on assumptions of future performance as follows:

- The remainder of the work will be completed according to the original time durations. As a result, the TEAC will only deviate from the schedule at completion (SAC) by the SV at the time of assessment.

- The remaining work will be completed at the same rate as the rest of the project. This means that the current rate of delay or acceleration will be maintained throughout the project.

The traditional EVM metrics of SV and CV tend to be deceptive as the project continues beyond the planned project end-date, and they converge to zero because the PV remains constant while the EV approaches the PV $[19,25]$.

Therefore for ES, if the date of assessment is past the planned project completion date, we have:

- $\quad$ An Expected Accomplishment Rate (EAR), which is defined as the rate of accomplishment of work per time-period from the time of assessment to the completion of the project, is used to estimate the end date.

- When performance-to-date is considered a good indication of future performance, the EAR is equal to the Actual Accomplishment Rate (AAR) [17].

The forecast metrics should be used for making directive decisions. The use of such metrics to influence project performance and decision-making is further investigated in this research.

\subsubsection{EVM and project uncertainty}

Projects have inherent uncertainty that results in deviations from the plans as the project unfolds [21]. High-tech, high-risk, and long-duration projects have the greatest uncertainty. Infrastructure projects are relatively well-defined, and variation from the plan is easier to control [21]. Traditional EVM is deterministic, while in reality projects are not. Acebes et al. [12] developed an extension to EVM that considers the inherent variability of activity costs and durations and uses Monte Carlo simulation to simulate a range of possible outcomes at any time of evaluation. By applying confidence intervals to the possible outcomes, the project manager is able to determine whether the deviation from the plan is within the random variability limits, and initiate control 


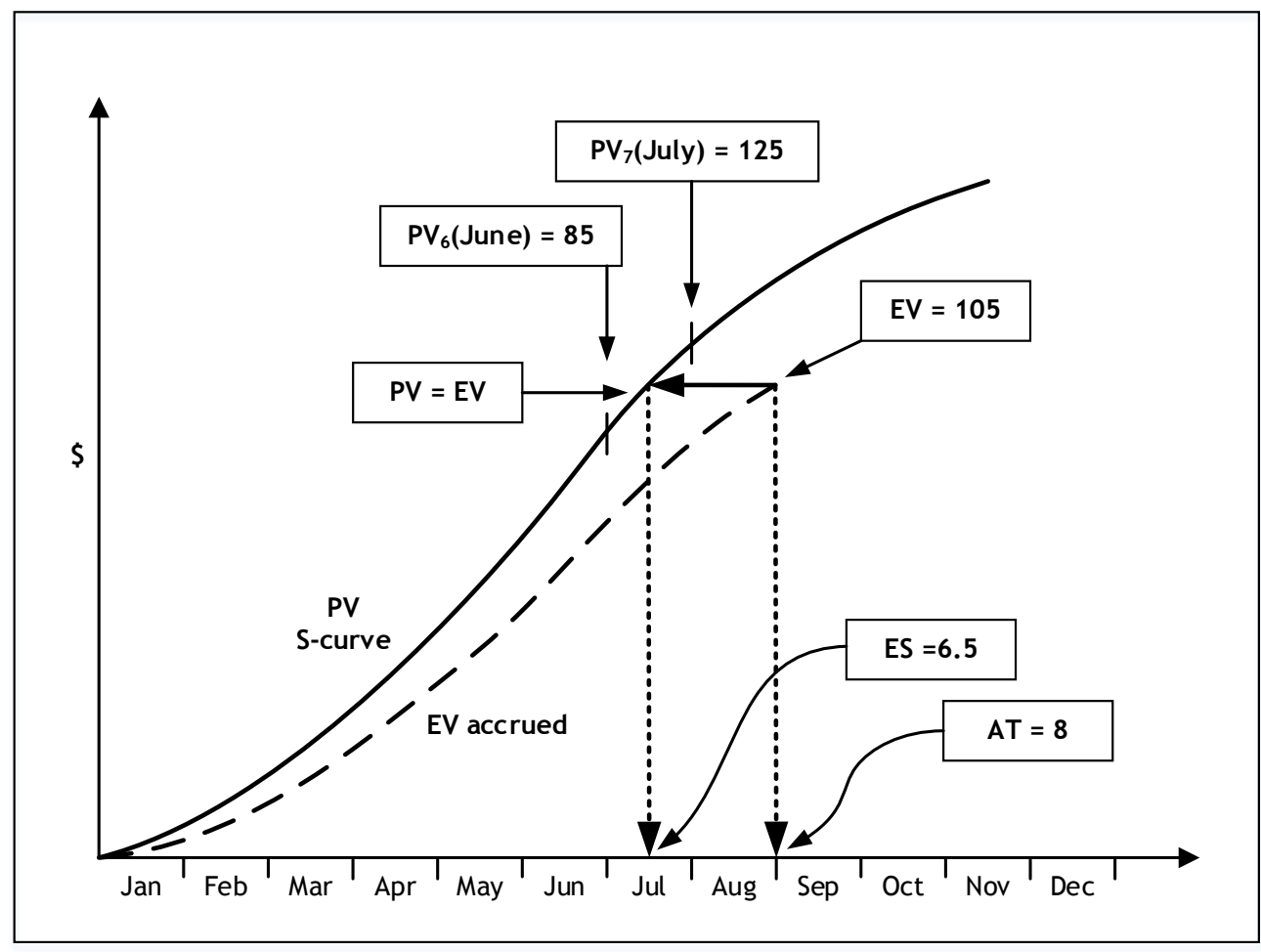

Figure 1: Graphical representation of Earned Schedule [19]

actions when necessary. The method of Acebes et al. [12] builds on the upper and lower limits developed by Lipke et al. [19].

As a result of the consideration of project uncertainty and the selection of a confidence interval for a project, the size of the buffer can be statistically determined. Buffer draw-down can be monitored, allowing the project manager even greater control of the project. The details of the calculations, which are available in Acebes et al. [11] and Lipke et al. [19], have been excluded from this paper.

\section{RESEARCH METHODOLOGY}

The case study research design was used to fulfil the stated objectives. The 'how' and 'why' nature of the research objectives suggests that case study research is appropriate [22]. The case that was studied is a large infrastructure project (ZAR 9 billion budget and five years' planned duration) where earned value management is used for project control. The project is managed as a family of NEC3 contracts with multiple principal contractors for the different work packages, with the project manager, who also happens to be the client, as the system integrator. The project is therefore effectively managed as a programme. Construction supervision for the different packages is provided by consultants, as well as by the client's own personnel for other packages for which the client is a specialist.

Different sources of data were used for the study. These included minutes of meetings, official correspondence, participatory observation, and semi-structured interviews conducted with the different project role-players. The semi-structured interviews were favoured because they allow for more responsive questioning to explore the interviewees' perspective. The selection of the interviewees was based on their role on the project. Project managers/clients, consultants/supervisors, and contractors were targeted, starting with the most senior in each organisation and moving down the hierarchy based on the involvement of the organisation in this case's EVM structure. 
Nine interviews were conducted; a summary of the interviewees is shown in Table 1. The interviewees have 120 years between them of project experience, at an average of 13 years per person. However, they have a total of 16 years' EVM experience between them at an average of just under two years each. Most notably, consultants have the least EVM experience of the three parties. Consultants are typically only responsible for the technical deliverable of a project, and the lack of EVM experience is the first indicator that EVM feedback does not normally cascade down to all stakeholder levels.

Table 1: Summary of interviewees

\begin{tabular}{|c|c|c|c|c|}
\hline Category & $\begin{array}{l}\text { Number of } \\
\text { interviewees }\end{array}$ & Designations & Number of packages & $\begin{array}{c}\text { Project } \\
\text { experience } \\
(\mathrm{EVM}) \text { in years }\end{array}$ \\
\hline $\begin{array}{l}\text { Client/ } \\
\text { Project } \\
\text { manager }\end{array}$ & 4 & $\begin{array}{l}1 \text { project } \\
\text { controls } \\
\text { manager } \\
1 \text { package } \\
\text { project manager } \\
2 \text { contracts } \\
\text { managers }\end{array}$ & $\begin{array}{l}22 \text { (entire project/programme) } \\
1 \text { (main civil package } 8 \text { ) } \\
3 \text { (main civil package } 8, \text { M\&E } \\
\text { package } 12 \text {, mechanical auxiliaries } \\
\text { package } 13 \text { ) }\end{array}$ & $\begin{array}{l}16(4) \\
19(3) \\
16(6) \text { and } 15 \\
(3)\end{array}$ \\
\hline Contractor & 2 & $\begin{array}{l}1 \text { project } \\
\text { manager } \\
1 \text { site manager }\end{array}$ & $\begin{array}{l}1 \text { (main civil package } 8) \\
1 \text { (M\&E packages } 12 \text { \& } 13 \text { ) }\end{array}$ & $\begin{array}{l}+/-20 \\
\text { (unspecified) }\end{array}$ \\
\hline $\begin{array}{l}\text { Consultant } \\
\text { supervisor }\end{array}$ & 3 & $\begin{array}{l}1 \text { chief } \\
\text { supervisor } \\
1 \text { senior } \\
\text { supervisor } \\
1 \text { assistant } \\
\text { supervisor }\end{array}$ & $\begin{array}{l}2 \text { (construction supervision, main } \\
\text { civil package } 8, \text { M\&E package } 12 \text { ) } \\
1 \text { (M\&E package } 12 \text { ) } \\
1 \text { (main civil package } 8 \text { ) }\end{array}$ & $\begin{array}{l}14(0) \\
10(0) \\
10(0)\end{array}$ \\
\hline
\end{tabular}

\subsection{Opinions of the roles of EVM in project controls}

The client interviewees were of the opinion that EVM is a best practice for project control and is applicable to all projects. Consultants agreed that EVM was applicable to all projects, and that it should be used more in the project environment than is currently the case - although only one of the three consultant interviewees had some EVM awareness. The contractors expressed scepticism about the adequacy of EVM for controlling fixed-price contracts on milestone-based payment projects and for large projects. This response is attributed to the contractors' lack of prior experience or training in project management, and specifically in EVM methods.

\subsection{Level of EVM awareness and understanding}

In a mature project environment, it would be expected that the client and the project suppliers use EVM to monitor and control their own work. That was not the case for this particular project, however.

The level of EVM awareness with the client/project manager was high. This was attributed to the fact that the client/project manager was the only party on the project who was implementing EVM. Knowledge was limited to the more traditional metrics of SV, CV, CPI, and SPI. These are descriptive measures that refer to past project performance and not to predicted future performance. This indicates that EVM is used only for monitoring and not for directive control.

EVM awareness amongst consultants was low, and only one of the three interviewees was aware of EVM as a tool and of its use on the project. The contractors were not aware of EVM use on the project. This lack of awareness from the other two parties on a work package suggests that EVM is confined to one party of the project, with the result that EVM can only possibly influence one party's decisions. Although the other two parties should implement the PM's decisions, these decisions may be subject to change management processes, contractual scrutiny, and disputes, and the effect on daily project work can be delayed. 


\subsection{Motivation to implement EVM on the project}

The choice to implement EVM on the project was a personal one for the client controls manager, although there was an effort to standardise EVM in the client's organisation. The selection was based solely on consideration of EVM as best practice and the contract type, and thus risk mitigation was not a factor. The client/project managers were generally of the opinion that EVM should be implemented for all types of projects. The consultants/ construction supervision did not use EVM because they were only responsible for the quality on the project, and had no obligation for schedule and cost performance on the NEC contract. This situation is specific to the case study; in other situations, consultants/ construction supervision might be responsible for work packages, which could benefit from EVM.

Revenue-based accounting and the contractual schedule are the preferred project control tools for the consultants. Similarly, contractors do not use EVM because it is deemed inadequate for controlling large projects. Industrial cost accounting is used for cost control, and the contractual schedule is used for controlling time. The reason for the apparent scepticism about EVM is not clear, since the cost accounting methods that are used can easily be extended to include EVM methods and to reap the benefits of EVM.

\subsection{Dependence on contract type (risk distribution)}

No relationship was found between the contract type and the motivation to use EVM. There was a lingering uncertainty about the applicability of EVM to fixed price contracts. This is attributed to the understanding of EVM as merely a cost control tool rather than a powerful and integrated cost, time, and performance tool.

\subsection{Difference in use between contractors, consultants, and clients (roles)}

In November 2012, four years into construction, the client started to use EVM to analyse the project's performance. The high occurrence of compensation events and the risks associated with the client's role as system integrator were specifically analysed. The analysis showed that additional time and budget were required to complete the project, which was the reason for allowing additional funds and time. The new projected cash flows were adopted as the baseline for monitoring project performance. Although the TCPIs were calculated, the focus of the EVM report was on past project performance.

EVM is neither an organisational nor a contractual requirement on the project; hence, contractors and consultants did not use EVM, preferring other methods of project control. The contractors did acknowledge that EVM parameters could be calculated from their contractual control tool (the project schedule). The client introduced EVM late in the project, and it was not feasible to attempt to get the contractors and consultants to change to EVM methods. There was therefore no compelling need for EVM, since it was not a contractually-required project control method, and contractors did not feel that EVM would add value to their control process.

\subsection{Implementation of EVM on the project}

As already mentioned, only one party of the project implemented EVM. It was clear that EVM was confined to the one party, as the interviewees from the other parties were not familiar with the performance of the project or their work packages in terms of EVM metrics. Even among those in the EVM reporting loop, there was a feeling that the tool was restricted to higher levels of the project structure, and did not reach or influence those at the coalface. Lack of awareness in the construction supervision team and the contractor attested to this. Since EVM was not a contractual requirement, there was no basis for discussing project performance on EVM metrics at meetings between the client/project manager, the supervisor/consultant, and contractors. The use and interpretation of EVM therefore mainly benefitted the client, and added little to the conversation with the contractors and consultants. The project manager did communicate the interpretation of the EVM results to the consultants and contractors but, due to their limited knowledge of EVM, this communication was done as an informative measure and not for primary progress reporting.

\subsection{Reporting structure and process}

EVM data was collected at work package level, and models for each active work package were generated; these were then rolled up to project level to determine the total project performance. A monthly report was generated and a 'robot' buffer monitoring system was used to indicate the health of the buffer. The report was discussed among executive project management and package- 
level project managers to exploit gains and focus on problem areas. The project was deemed to be in control if the CPI and SPI were between 0.9 and 1.1 respectively.

\subsection{Level of use in decision-making}

An investigation into key decisions that affect daily project work, such as the drawing up of an incentive bonus schedule and assessment and subsequent rejection of a contractor's submission of a schedule, revealed that EVM had no input into such decisions. These decisions were performance-based, where EVM was expected, at the very least, to be an input into the decisionmaking. This was, however, not a qualification of the decision, but merely an assessment of the use of EVM as a decision-making tool. At most, the operations-level project managers (i.e., work package project managers) used EVM tacitly for decision-making.

For contractors and construction supervision, even the tacit use of EVM for daily decision-making was dismissed. Although the construction supervision team viewed their role as contractually independent of cost and schedule performance, the supervisor was required to be pragmatic in his/her approach to construction supervision; he/she carried out pro-active in-process quality control that ensured quality processes did not result in unnecessary delays to project work.

\subsection{Effect on project performance}

EVM was seen to have positively affected project performance. It was said to have given the project direction and allowed project management to focus on problem areas. Figure 2 shows project performance for the entire project, while Figure 3 shows the CPI and SPI for the largest work package. From the run charts, it is clear that the project performed well after the implementation of EVM. However, it is debateable whether the baseline was obtained in the correct way. Some interviewees felt that performance should be measured against the contractual schedule, which is re-baselined only with approved Compensation Events (CE) that add work initially overlooked during scoping and procurement. Other CEs should not change the baseline, but should be reflected on the buffer health status or buffer consumption, since compensation events are materialised risks and the buffer is set up for risk management.

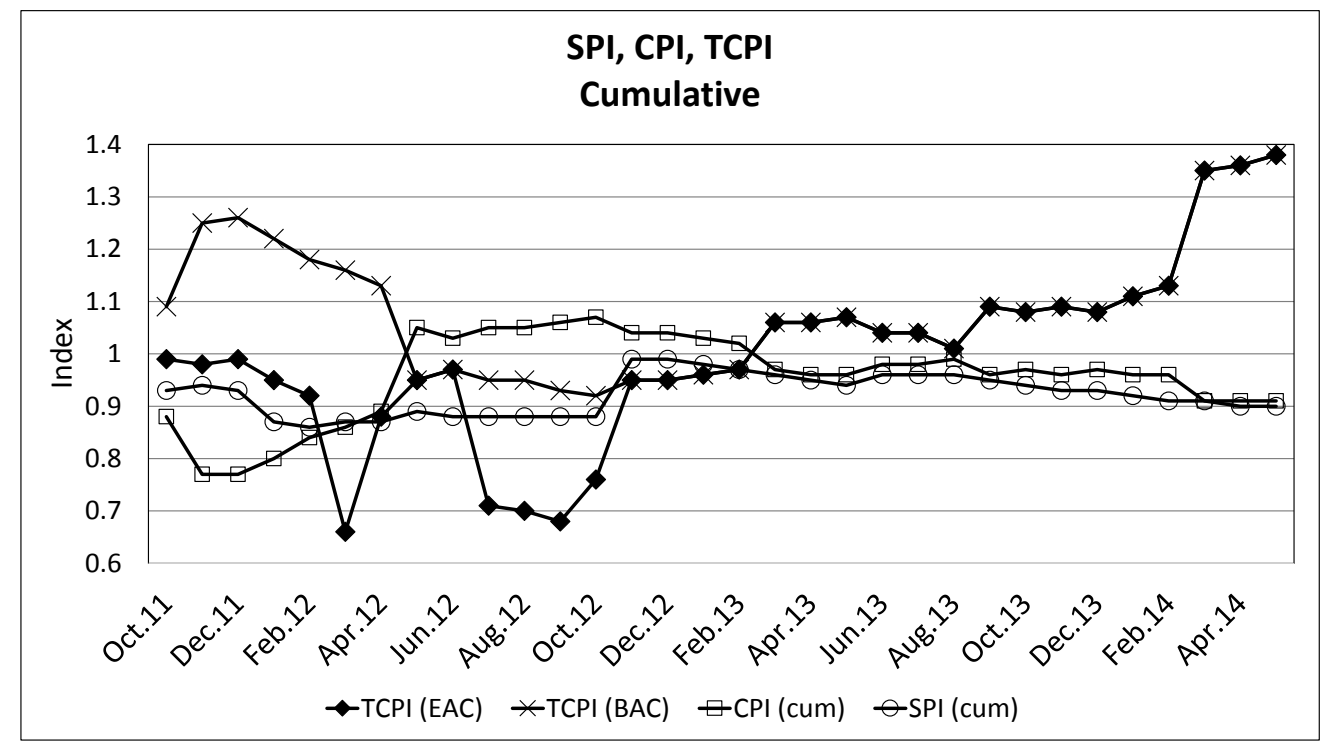

Figure 2: Performance run chart for the entire project 


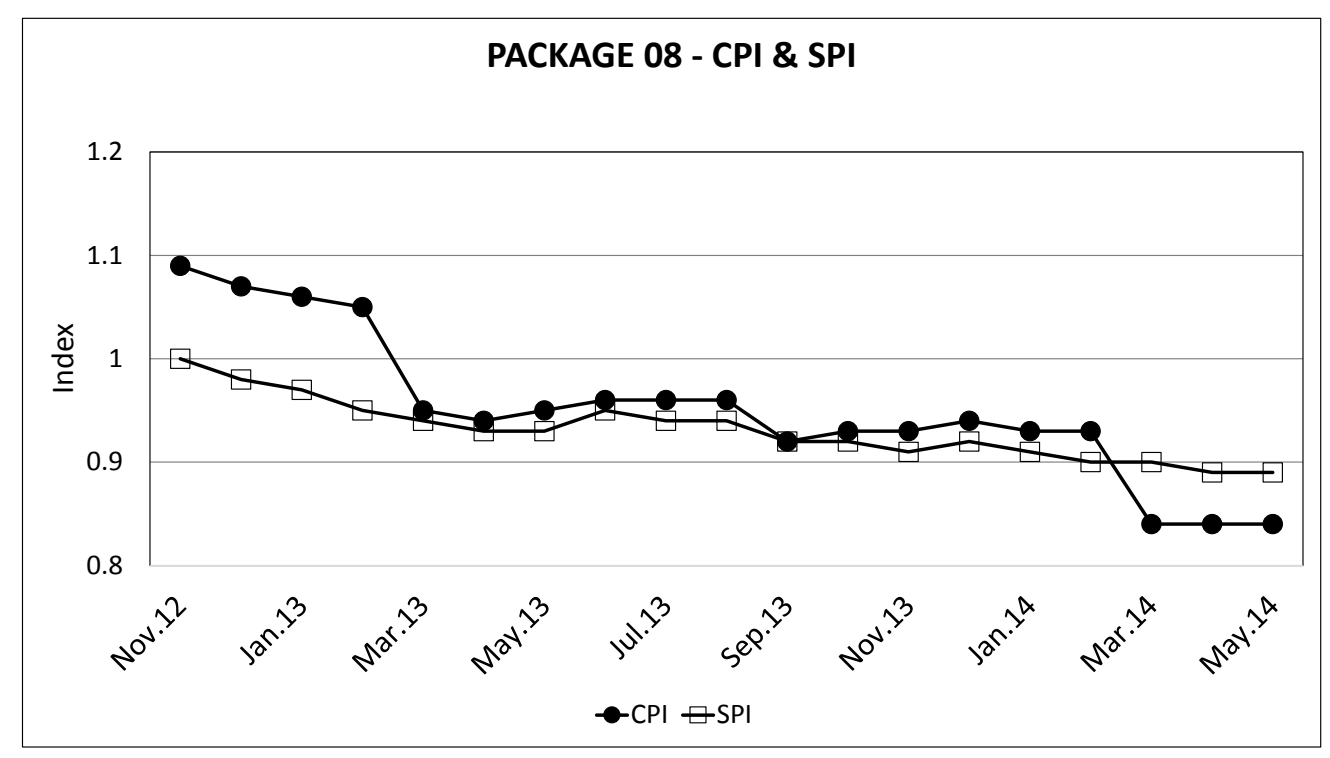

Figure 3: Performance run chart for the largest work package

A project's high exposure to compensation events is often an indicator of poor front-end loading, and most client and consultant interviewees believed this to be the case. These compensation events materialise during construction, and are reflected in the construction phase performance measures. This creates the perception of problems in the construction phase when, in fact, these compensation events are symptoms of poor front-end planning.-Thus the seemingly 'doctored' baseline is in fact a separation of project phases and application of EVM to the construction phase only. This was done in 2012, some four years into the construction phase, and shows the extent of the compensation event exposure due to poor front-end loading. The total variance attributable to construction phase performance remains contentious.

\section{CONCLUSION AND RECOMMENDATIONS}

The results of this research suggest a link between EVM use and project management maturity. The suggested overlay of EVM use on maturity requires further research for validation. This proposition is based on Lukas' [20] assertion that only level III and higher project management mature organisations should use EVM. The proposed links between maturity levels and EVM are as follows:

- $\quad$ Level III: Having project management processes in use and in place across projects. Individual project managers who understand the methodology use EVM in isolated projects as a matter of preference. Basic standard metrics such as CPI and SPI are used mainly for monitoring progress and performance. Communication to the project team about EVM is non-existent.

- Level IV: Project management processes are in place and EVM adoption gains popularity, and adoption increases across projects. EVM is used as a forecasting tool, and some decisions, particularly high-level ones, are made with EVM as an input. Performance communication is limited by the project team hierarchy.

- Level V: Project management processes are engrained in all project work. Emphasis is on front-end loading, with EVM as standard practice in all contracts. Specialised software packages with a project support and EVM are part of daily project work and influence decisions at most levels of the project structure. More complex metrics such as earned schedule and TCPI are well understood by decision-makers.

This, however, does not imply that projects conducted by organisations at maturity levels II and I will necessarily fail; Marnewick [23] shows that they can be successful. The client for the studied case was classified as a Level IV organisation, based on its project management processes and use of EVM. 


\subsection{Using EVM to initiate direct control actions}

To initiate directive control decisions based on EVM, it must be a contractual requirement upon which a common understanding of performance can be reached with all the performanceinfluencing parties in a project. Level $\mathrm{V}$ project mature organisations can achieve this, as all the requirements for effective EVM implementation are in place.

\subsection{Effect of control decisions on daily work}

The contractor is the closest to daily project work, followed by the supervisor, while the contractor, followed by the project manager, has the greatest influence on schedule and cost. The contractor's influence is more direct, whereas the project manager's influence is regulated by the contract; and so, without contractual leverage, which is diminished by the project's susceptibility to compensation events/variations, the project manager's influence is minimal. The project manager communicates the decisions by means of letters and instructions. The effect of performance instructions such as increasing resources or expediting work (which are not always discernible as methods) are contractually the contractor's responsibility. The contractors only respond in ways that benefit them - for example, in response to performance bonus target dates and in passing risk to others in anticipation of compensation events.

\subsection{Effect of EVM on project performance}

The project manager, who was the only party to use EVM, perceived EVM to have positively affected project performance. However, the fact that the baseline is not based on the contractual schedule, but on projections based on past performance and anticipated further compensation events, suggests that the method has been influenced to show good news. A more pragmatic perspective is that EVM was used to revise the plan to a more realistic plan on which negotiations for resources and time from the project sponsor can be based. This was concluded in November 2012, and performance was closely linked to this new baseline, which is more an indication of the accuracy of the EV projections than of EV-controlled performance.

\subsection{Effect of the lack of EVM contractual specification}

The lack of EVM as a contractual requirement diminished the directive use of EVM. The parties to a contract cannot have a common understanding of performance in terms of earned value metrics. Discussions in any official correspondence across project role-players/parties cannot be in terms of EV metrics. This confines EVM to one party in a project, and so only that one party's decisions can be based on EV metrics. In this case, the earned value's input into such decisions was implicit, at best. This was also attributable to a limited understanding of EVM, and in particular of the future tense performance metrics such as TCPI.

The contractually-specified performance measures were the contractual schedule (time), the bill of quantities (cost), and the technical specification (quality). It is important to note that EVM is not touted as a replacement for any of these, but as an additional tool that integrates all three.

\subsection{Relationship between the motivation for implementing EVM and contract type}

No relationship was found between the motivation for implementing EVM and contract type (financial risk allocation). Only a lack of appreciation of the integration of cost schedule and quality in EVM was found to influence the opinion that EVM is not applicable to fixed price contracts. EVM was, in the opinion of one contractor, inadequate for controlling large projects; this opinion is in direct contrast to findings by Anbari et al. [17]. This is of particular interest, because the particular contractor is doing very well and is in control of their performance. The preferred method for the contractor is a more detailed industrial cost accounting method, which focuses only on costs and not the triple baseline that EVM integrates. This is because cost control is paramount for the profitability of a contractor, and the most potent control method is preferred, whereas the client may be willing to pay a premium to complete the project and start realising the benefits. Schedule is controlled by means of the contractual schedule and compensation events.

\subsection{Recommendations}

While EVM is not a pre-requisite for a project to be in control, if EVM is to have full impact on an infrastructure project (i.e., monitoring and directive control), it must be contractually specified in order to ensure a common understanding of project performance between the different roleplayers on the project. Feedback in terms of EVM metrics must be available at all levels and 
adapted and simplified as required; in this way, EVM will have at least a tacit effect on project decisions at all levels. A structured approach to decision-making for such decisions based on TCPIs must be implemented to influence future project work. Validation of the link between project management maturity and EVM use is required.

This study has revealed some insights into the implementation of EVM in infrastructure projects. A wider population of project professionals could be studied by using a survey research design. The use of EVM by contractors was revealed as an unexplored subject, with suggestions that EVM provides only high-level control. EVM applicability to such contractors could thus be limited to reporting at portfolio-level control rather than project control.

EVM applicability to Critical Chain Project Management (CCPM) should also be further investigated. Indications in Christ [15] are that two schedules are necessary to apply EVM to CCPM-planned projects, especially with regard to the project buffer zone where, at planning stage, no activities are scheduled and so no cash flows are be anticipated. The question that remains is how the EV and the related performance index curves will behave, since there is no explicitly-specified budgeted work. This requires further research.

\section{REFERENCES}

[1] National Planning Commission. 2013. National Infrastructure Plan. Retrieved from: http://www.info.gov.za/issues/national-infrastructure-plan/. Accessed on 5 October 2013.

[2] Mokgabudi, T. 2013. Planned infrastructure expenditure and the NDP. Mind the gap. KPMG. Retrieved from: http://www.kpmg.com/ZA/en/IssuesAndlnsights/ArticlesPublications/General-IndustriesPublications/Documents/Mind\%20the\%20gap.pdf. Accessed on 24 March 2014.

[3] Radebe, K. 2013. Missing the R11.8 trn NDP's infrastructure target. Retrieved from: http://www.moneyweb.co.za/moneyweb-south-africa/missing-the-r118trn-ndps-infrastructure-target. Accessed 24 March 2014.

[4] National Planning Commission. 2013. Key Issues - National Development Plan. Retrieved from: http://www.gov.za/issues/national-development-plan/. Accessed 24 March 2014.

[5] Jackson, S. 2002. Project cost overruns and risk management. In Proceedings of Association of Researchers in Construction Management 18th Annual ARCOM Conference, Newcastle, Northumber University, UK (pp. 2-4).

[6] Wong, P.S.P., Cheung, S.O. and Wu, R.T.H. 2010. Learning from project monitoring feedback: A case of optimizing behaviour of contractors, International Journal of Project Management, 28, pp. 469-481.

[7] Al-Jibouri, S. 2003. Monitoring systems and their effectiveness for project cost control in construction, International Journal of Project Management, 21, pp. 145-154.

[8] Cioffi, D.F. 2006. Completing projects according to plans: An earned value improvement index, Journal of the Operational Research Society, 57, pp. 290-295.

[9] Vandevoorde, S. and Vanhoucke, M. 2006. A comparison of different project duration forecasting methods using earned value metrics, International Journal of Project Management, 24, pp. 289-302.

[10] Logan, C. 2014. Interview by author with the Chief Supervisor of Gibb Engineering \& Architecture. [Transcript] 5 June: Ladysmith.

[11] Acebes, F., Pajares, J., Galán, J.M. and López-Paredes, A. 2013. Beyond earned value management: A graphical framework for integrated cost, schedule and risk monitoring, 26th IPMA World Congress, Procedia - Social and Behavioural Sciences, Crete, Greece 2012. Crete 74, pp. 181-189.

[12] Acebes, F., Pajares, J., Galán, J.M. and López-Paredes, A. 2013. A new approach for project control under uncertainty: Going back to the basics, International Journal of Project Management, 32(3), pp. 423-434.

[13] Kim, E., Wells, W.G. and Duffey, M.R. 2003. A model for effective implementation of Earned Value Management methodology, International Journal of Project Management, 21, pp. 375-382.

[14] Pillay, D., Steyn, H. and Sommerville, J. 2013. The application of Earned Value Management to manage project costs within the South African municipal infrastructure sector, African Journal of Public Affairs, 6(1), pp. 108-121.

[15] Christ, D.K. 2001. Theory of constraints project management in aircraft assembly. Boeing, pp. 1-26.

[16] Song, L. and Shalini, H. 2009. A global and cross-industry perspective on EVM practice and future trends. Construction Management: Survey Summary Report, University of Houston.

[17] Anbari, F. T., Cioffi, B. F., and Forman, E. H. 2010. Integrating performance measures to exert effective leadership in managing project portfolios. Paper presented at PMI Research Conference, Washington, DC.

[18] Lipke, W. 2003. Schedule is different. Retrieved from: http://www.earnedschedule.com/docs/schedule\%20is\%20different.pdf. Accessed 28 January 2015.

[19] Lipke, W., Zwikael, O., Henderson, K. and Anbari, F.T. 2009. Prediction of project outcome: The application of statistical methods to earned value management and earned schedule performance indexes, International Journal of Project Management, 27, pp. 400-407.

[20] Lukas, J.A. 2008. Earned value analysis - why it doesn't work. AACE International Transactions. 
[21] Nicholas, J.M. and Steyn, H. 2012. Project management for engineering, business and technology. $4^{\text {th }}$ edition, Routledge.

[22] Yin, R.K. 2009. Case study research design and methods. $4^{\text {th }}$ edition, Sage Publications.

[23] Marnewick, C. (ed.). 2013. Project management maturity vs project outcomes in Africa. Project Management South Africa, 2013, pp. 20 and 22.

[24] Anbari, F.T. 2003. Earned Value Project Management method and extensions, Project Management Journal, 34(4), pp. 12-23.

[25] Lipke, W.H. 2009. Earned schedule. Lulu Publishing.

[26] Du Preez, Max. 2014. Our protest culture is far from dead, Pretoria News, 11 February 2014. 